\title{
WestVirginiaUniversity
}

THE RESEARCH REPOSITORY @ WVU

West Virginia Agricultural and Forestry Experiment

Davis College of Agriculture, Natural Resources

Station Bulletins

And Design

$1-1-1962$

\section{Expanding the demand for floricultural products sold by florists}

Roger W. Pease

Follow this and additional works at: https://researchrepository.wvu.edu/ wv_agricultural_and_forestry_experiment_station_bulletins

\section{Digital Commons Citation}

Pease, Roger W., "Expanding the demand for floricultural products sold by florists" (1962). West Virginia Agricultural and Forestry Experiment Station Bulletins. 477.

https://researchrepository.wvu.edu/wv_agricultural_and_forestry_experiment_station_bulletins/449 @ WVU. It has been accepted for inclusion in West Virginia Agricultural and Forestry Experiment Station Bulletins by an authorized administrator of The Research Repository @WVU. For more information, please contact ian.harmon@mail.wvu.edu. 

Digitized by the Internet Archive in 2010 with funding from

Lyrasis Members and Sloan Foundation 


\section{Expanding the Demand For Floricultural Products Sold by Florists}

ROGER W. PEASE

\section{Introduction}

THE florist business depends primarily upon the so-called "special 1 event" trade: holidays, gala occasions, births, marriages, and deaths. Various attempts have been made to broaden the market by such merchandising techniques as comparatively low-priced weekend specials' and convenient carry-home packs. ${ }^{2}$ Although such projects sometimes have resulted in net profits, the increases in sales volumes have been relatively small and, possibly, at the expense of higher-priced sales or of sales by other florists in nearby areas.

The effects of progressive merchandising techniques within a given area are difficult to measure where cities or towns are close to each other; where patronage can shift from town to town, from florist to florist, or from florist outlets to non-florist outlets; or where a rather complete analysis of records cannot be made over a period of several years.

\section{The Areas Studied}

In an effort to measure the effects of programs to expand the market for flowers, two areas in West Virginia were chosen for study. Area I was a county comprising about 650 square miles. Its county seat and largest town had a population of about 2,500 in 1960 . One combined greenhouse-florist shop was located in the county seat. There were no other florist shops in the county. ${ }^{3}$ One city in an adjoining county had a population of more than 20,000 , but it was separated from the area to be studied by about 25 miles of mountain road. The greenhouse-florist business to be analyzed had been purchased in

1 Merchandising for Profit in Retail Flower Shops, P. B. Pfahl, et al., Bul. 659, Y2. State U. Agr. Exp. Sta., University Park, Pa., Aug. 1959.

2 The Aqua Pak-A New Package for Selling Cut Flowers, High Burrell, Cornell U. Agr. Exp. Sta., A.E. 1060, April 1957.

3 During the last three years of the period under study, one florist with no formal shop was competing in the county. 
1948, and from 1949 through 1959 the owners had followed a policy of expansion. However, the outlets for their floral ${ }^{4}$ products had remained local. In 1958 they marketed only five funeral arrangements outside of the county. All of their sales were either at retail or on a consignment basis through various non-florist outlets within the county. The area's comparative isolation also discouraged competition from other trade centers.

The other area chosen for study, Area II, was a county comprising about 1,000 square miles. The county seat and trading center was a city with about 8,000 residents. All of the florists within the county were located in the county seat, and the nearest out-of-county florist was about 30 miles away. One greenhouse-florist in the county seat had adopted a program of expansion. This concern was chosen for study in the hope that the effects of its program could be determined.

\section{AREA I}

Figure $1^{5}$ compares the dollar value of floricultural sales by Florist A with the dollar value of the county's total retail sales ${ }^{6}$ after the floricultural sales had been deducted. During seven of the ten years involved, floricultural sales and other retail sales rose and fell togetherin direction, but not always in degree.

Before 1955 the pattern of floricultural sales tended to follow the pattern of other retail sales. The relatively extreme rise and the compensating fall in floricultural sales in 1950 and 1951 probably reflected adjustments made following Florist A's purchase of the business in 1948. However, after 1955, the increases in floricultural sales were proportionately much greater than were the corresponding increases in other retail sales, and in 1959 floricultural sales held steady while other retail sales dropped about 14 per cent. During 1956, 1957, and 1958 something apparently caused floricultural sales to increase proportionately much more than other retail sales.

The dollar volume of florists ${ }^{7}$ sales in West Virginia rose about 10 per cent between 1949 and 1954 and about 31 per cent between 1954 and 1959. In Area I, however, florists' sales dropped about 4 per cent between 1949 and 1954 and rose about 55 per cent between 1954 and 1959. Some local influence apparently affected florists' sales in Area I.

Figure 1 shows total floral sales, and the differences which it indicates might not apply to the sale of funeral arrangements. Figure 2

${ }^{4}$ The terms floral sales and floricultural sales are used interchangeably throughout this bulletin.

5 In Figure 1 and subsequent figures which are presented during the analysis of Area I, an average of the years $1951,1952,1953$ was used as an index of 100 per cent. Sales volumes were relatively uniform during this period.

- Personal Income and Retail Sales in West Virginia by Counties, West Virginia Chamber of Commerce, April 1960; Table VI, p. 8.

7 Census of Business, U. S. Department of Commerce, 1960; B58, RA48. 
Figure 1. Floral Sales of Florist $A$ and County Retail Sales Minus Floral Sales (Dollar volumes from 1949 to 1959, inclusive, with the average of 1951, '52, '53 sales as an index of 100 per cent)*

'er Cent

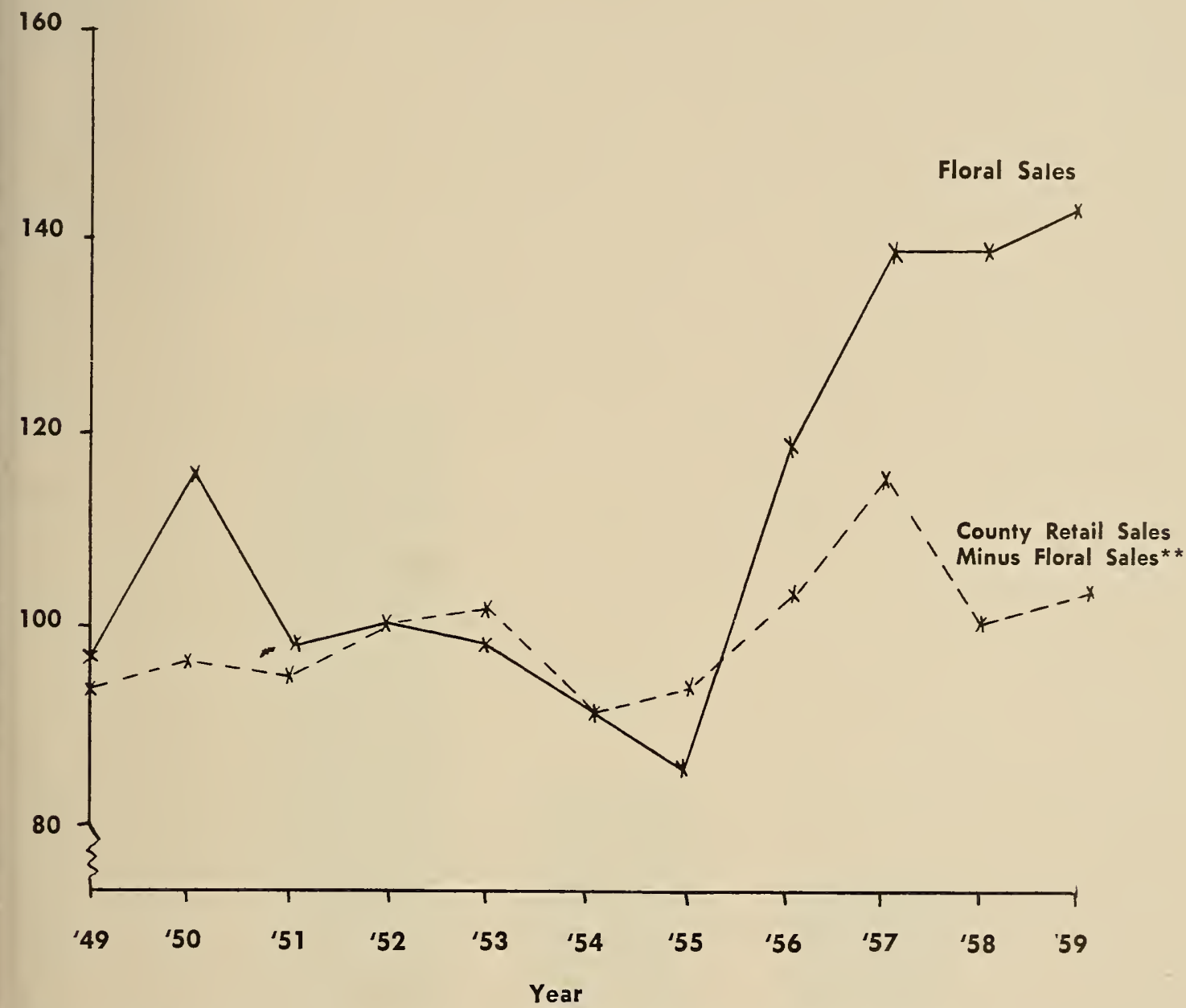

*The years 1951, 1952, and 1953 were chosen because sales volumes were relatively uniform during that period.

**Personal Income and Sales in West Virginia by Counties, West Virginia Chamber of Commerce, April 1960; Table VI, p. 8.

shows the patterns of floral sales for funerals and of other floral sales. In eight of the ten years involved, other floral sales decreased when funeral sales increased and increased when funeral sales decreased. Only in 1950 and 1954 did the two change in the same direction. Possibly non-funeral sales were used primarily to dispose of surpluses from funeral sales and were therefore inversely correlated with them. Funeral sales rose a total of about 90 per cent in 1956 and 1957, while other floral sales were dropping about 20 per cent. During this period some factor or group of factors must have caused funeral floral sales to rise sharply. If these factors had any direct effect upon non-funeral sales, the effect apparently was negative.

Figure 3 indicates that funeral sales returned about 60 per cent of the concern's total income over the ten-year period; a supplementary 
Figure 2. Floral Sales for Funerals and Other Floral Sales (Data from 1949 to 1959, inclusive, with the average of 1951, 1952, 1953 sales Per Cent

\section{as an index of 100 per cent)}

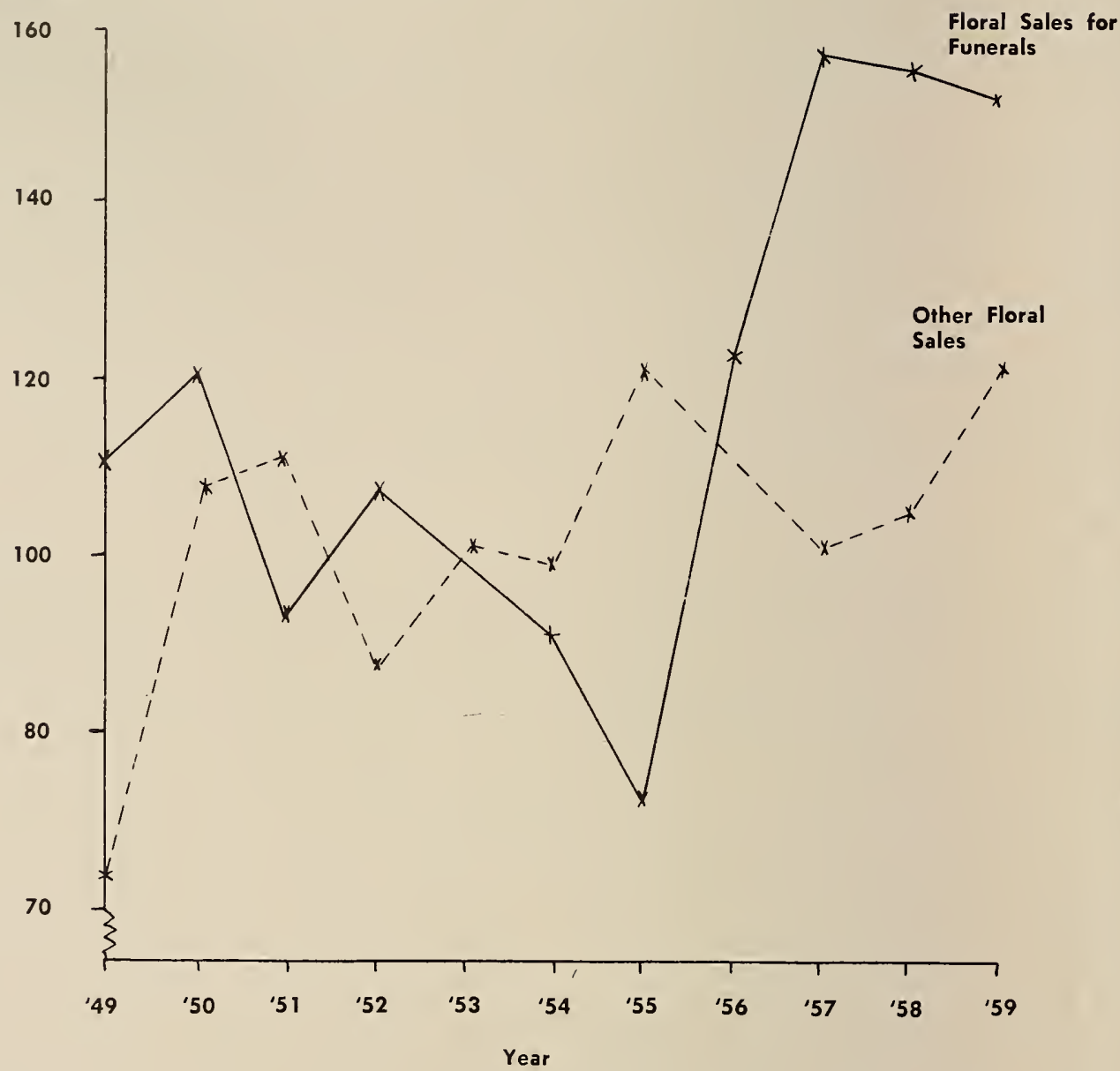

landscaping business, listed in the Figure as Trees and Shrubs, returned about 15 per cent; and non-funeral floral sales returned about 25 per cent. The relatively small volume of non-funeral floral sales supports the hypothesis that one of their chief functions was to dispose of plant materials not used in funeral sales.

Changes in the purchasing power of money, of population density, of per capita income, affect all sales; but funeral sales are especially affected by the recurrence of death. In the preparation of Figure 4, funeral floral sales first were deducted from total county retail sales. Second, adjustments were made for the purchasing power of money. ${ }^{\circ}$ Third, funeral floral sales were adjusted for the cumulative and simultaneous effect of changes in the number of deaths, ${ }^{9}$ of population

8 Statistical Abstract of the U. S., U. S. Department of Commerce, 1960; Table 432, p. 331 .

9 Photostatic Records from West Virginia State Department of Health. 
Figure 3. The Proportion of Gross Sales Made Through Each of Several Channels (Based on the total dollar value of the sales during a ten-year period 1949 to 1959 , inclusive)

Per Cent

100

80

Funeral Floral

Sales

Other Floral

Sales

40

60

40

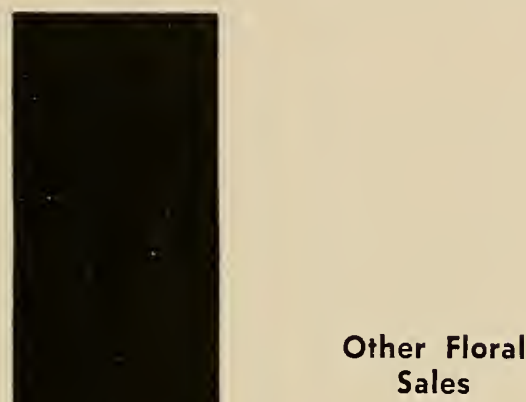

0

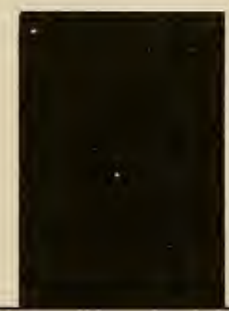

$$
\text { Sales of Trees }
$$
and Shrubs

changes, ${ }^{10}$ and of changes in per capita income. ${ }^{11}$ Fourth, county retail sales were adjusted for the cumulative and simultaneous effect of changes in population and per capita income but not for changes in the number of deaths.

As in Figure 1, the two patterns of sales shown in Figure 4 change in the same direction during seven of the ten years involved in this study, but in 1955 and 1956 increases in funeral sales were so great that the long-time trends of the two patterns are in opposite directions. The averages of sales during the last four years $(1956,1957,1958,1959)$

10 United States Census of Population, General 'Population Characteristics, West Virginla, U. S. Department of Commerce, 1960; Table 28, pp. 50-74. Yearly interpolations calculated from Census material.

11 Personal Income and Retail Sales in West Virginia by Counties, West Virginia Chamber of Commerce, April 1960; Appendix A, p. 10. 
Figure 4. Adjusted* Floral Sales for Funerals and Adjusted County Retail Sales Minus Funeral Floral Sales (Dollar volumes from 1949 to 1959, inclusive, with the average adjusted 1951, 1952, 1953 sales as an index

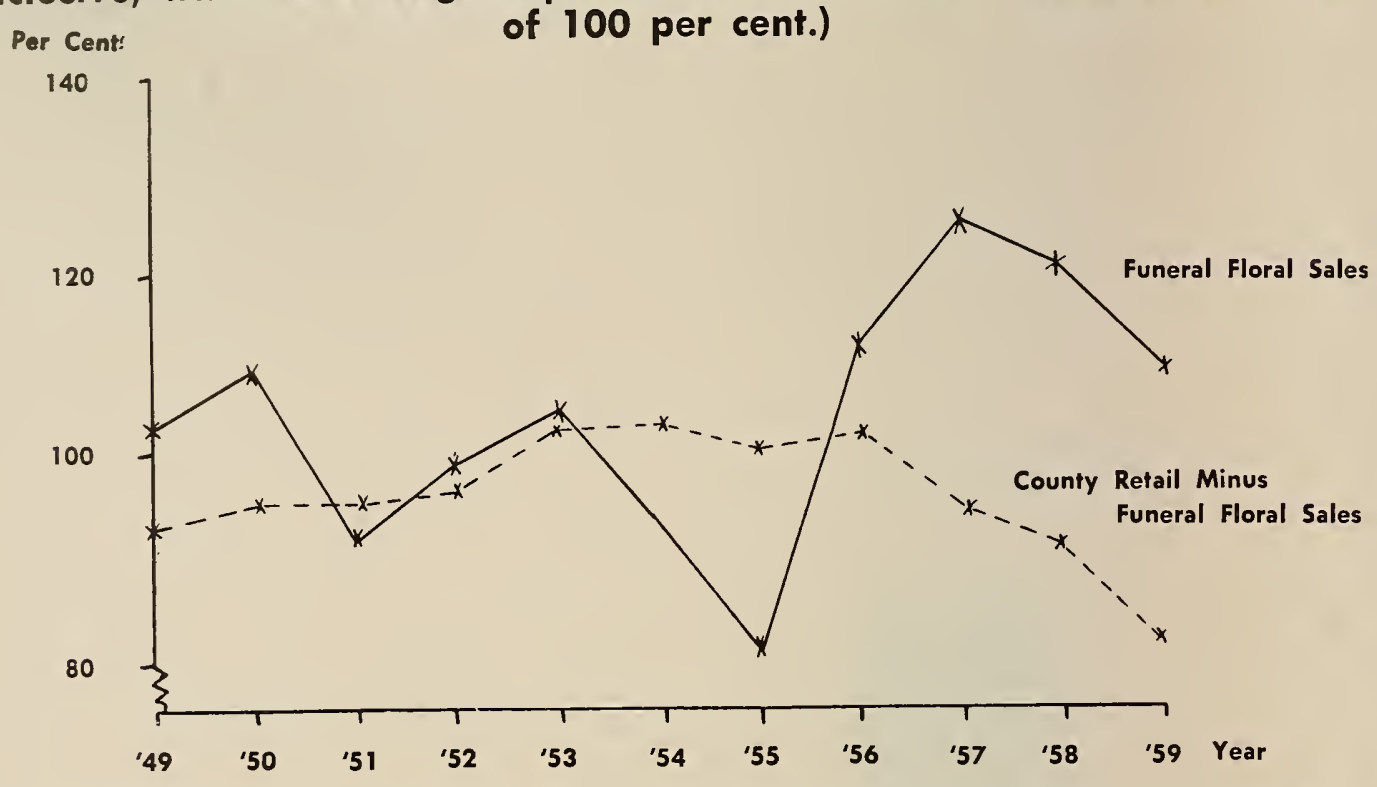

*Using 1951, 1952, 1953 averages as indices of 100 per cent, adjustments were first made for the purchasing power of money.** Then funeral floral sales were adjusted for a simultaneous effect of deaths*** population $\dagger$, and per capita income $\bar{t}$, and county retail sales minus funeral floral sales were adjusted for population and per capita income.

**Statistical Abstract of the U. S., U. S. Department of Commerce, 1960; Table 432, p. 331.

***Photostatic Records from W. Va. Department of Health.

$\dagger$ United States Census of Population, General Population Characteristics, West Virginia, U. S. Department of Commerce, 1960; Table 28, pp. 50-74, yearly interpolations calculated from census material.

$\ddagger$ Personal Income and Sales in West Virginia, West Virginia Chamber of Commerce, April 1960; Appendix A, p. 10.

were computed and compared with the base values (the averages of sales during 1951, 1952, 1953). The difference between the base and the last four-year average was much greater for funeral floral sales than for county retail sales. A comparable discrepancy would have happened by chance less often than once in one hundred times. ${ }^{12}$

An over-simplified definition of demand might be: The amount of an available product purchased during a given period of time while prices remain constant. A less simplified definition might be: Within a given area, demand for a product which is readily available is a function of the price of the product, the price of competing products, personal income, and personal taste and preference. Expressed in another manner: The demand for a product readily available in an area can be changed by altering tastes and preferences-provided outside competition is absent; prices of competing products remain parallel with

12 A Chi Square value of 6.63 was needed for the 1 per cent level. The value obtained was 28.40 . 
prices of the product under study; and adjustments are made for changes in the purchasing power of money, in population, in per capita income, and (for funeral floral sales) in the recurrence of death. All of these stipulations for changing demand were satisfied in Area I except maintaining parallel prices of competing products. One of the advantages of funeral floral sales is that they have few, if any, direct competitors except No flowers, please, and No flowers, please exerts its influence only upon tastes and preferences.

An analysis of the efforts made in Area I to expand floral sales might discover some of the factors which affected tastes and preferences and more than counteracted any depressing effect of No flowers, please. These factors might not be effective in another area or at another time-but they would indicate that the demand for funeral floral products can be increased by progressive merchandising and public relation techniques.

The owners of the greenhouse-florist concern (Florist A) in Area I pursued their policy of expanding sales without changing prices except "to keep pace with inflation." Their efforts could be classified into three objectives: to make the concern well-known throughout the area and to inspire public confidence; to offer unusual services to churches and non-profit organizations; and to build a preference for relatively large and expensive funeral flower arrangements.

In 1951 the owners started a supplementary business in ornamental trees and shrubs, ${ }^{13}$ and through it they soon performed landscape services throughout the area, thus stimulating public confidence and increasing familiarity with the concern. In Figure 5 the rapid expansion of this supplementary activity is contrasted to the expansion of other phases of the business.

Among the extra services offered to churches and non-profit organizations was a special offer for floral arrangements, whereby the purchaser could store the arrangements, free of charge, in the floristgreenhouse concern's refrigerating units. The arrangements could be removed from storage at any time for use at the next special event. Specific arrangements were used as often as six times. The only stipulation was that the customer should carry the arrangement to and from storage.

The owners attributed much of the 1956-57 rise in funeral floral sales to a company policy started in 1955. At this time the concern featured a large, especially designed casket wreath; although smaller, less expensive wreaths were still available for sale. Consequently, the

13 Its sales were not included in the analysis of the floricultural business. 
Figure 5. Relative Increases in Various Branches of Business. (The average dollar values of sales in 1957, 1958, 1959, expressed in per cents, with the average of $1951,1952,1953$ sales as indices of 100.)

Per Cent

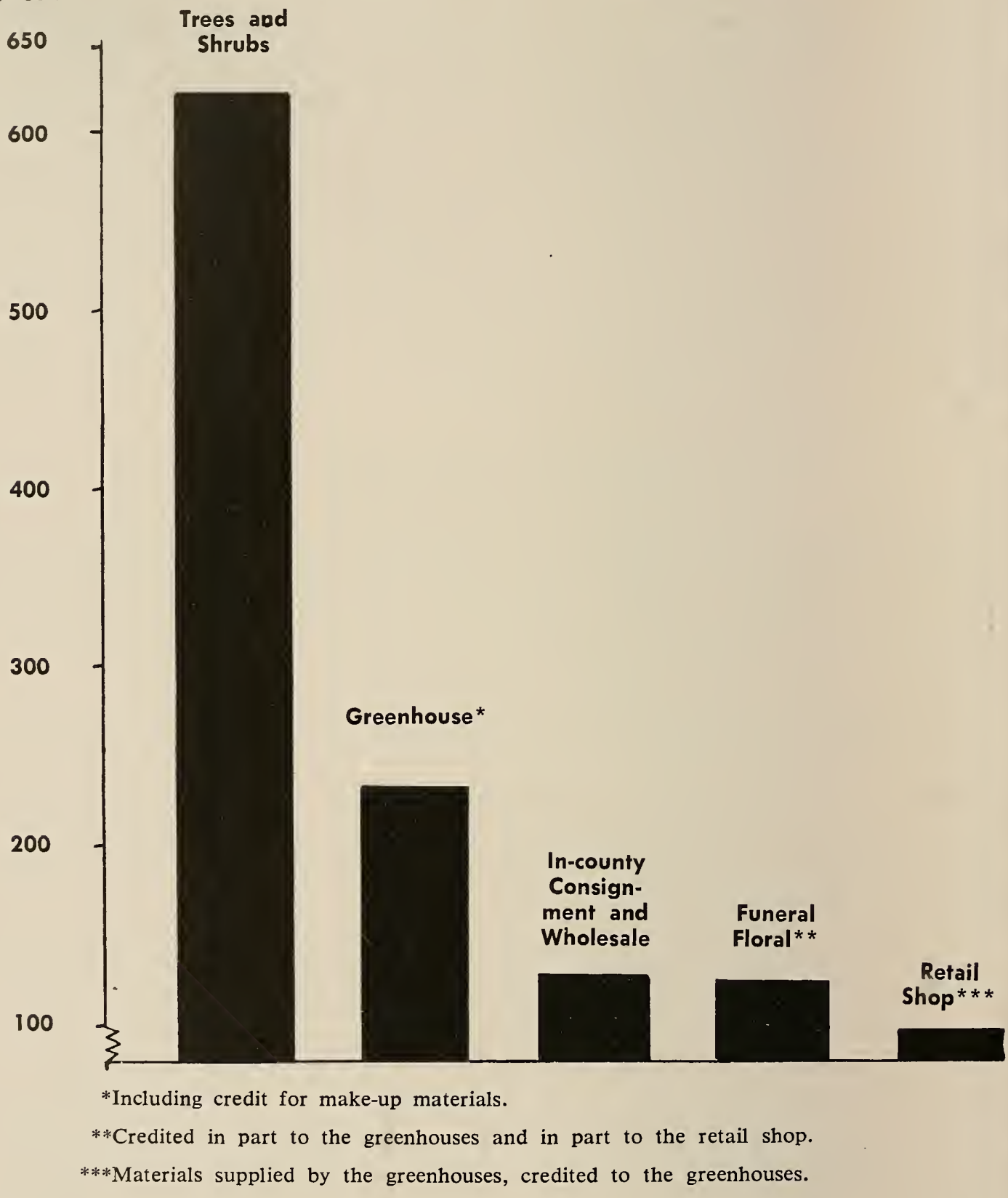

average income per wreath more than doubled between 1955 and 1959 . One of the owners commented: "Casket sprays used to be big at $\$ 15.00$; now we specialize in a $\$ 35.00$ minimum casket wreath (minimum for the special wreath)-really a new and more beautiful product we developed ourselves." The number of wreaths sold per funeral changed little, but the number of flowers and the income per wreath increased. 
Without the influence of the various activities which had won familiarity and confidence, the public may not have accepted the larger, more beautiful, and more expensive arrangements. The owners believe that a plateau for funeral floral sales was reached in 1958 or 1959, and that these sales henceforth will vary with the recurrence of funerals and with per capita income.

Figure 6 "shows that the sale of funeral arrangements comprised more than half of the company's total business. The shift in the demand

Figure 6. The Proportion of Recent Gross Sales Made Through Each of Several Channels (The average of 1957, 1958, 1959 funeral retail shop sales, in-county consignment and wholesale sales, greenhouse sales, sales of trees and shrubs, and funeral floral sales adjusted for deaths, expressed Per Cent as per cents of the average gross income)

55

40

50

30

20

10

0

*Funeral floral sales are not additive; that is, the sum of retail shop sales, consignment and wholesale sales, greenhouse sales, and sales of trees and shrubs is 100 per cent. Funeral floral sales are distributed among greenhouse and retail shop sales.
Funeral Floral*

In-county

Consign-

ment and

Wholesale

Greenhouse

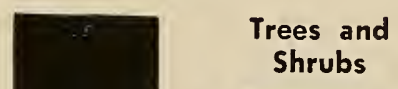

Shrubs
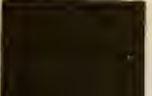

P
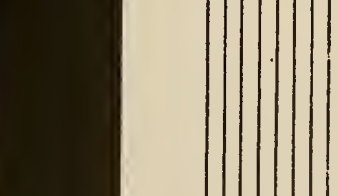

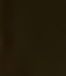


for floricultural products would have been too small to measure if the concern had not succeeded in enlarging funeral floral sales.

\section{AREA II}

The analysis of the florist business in Area II differed from the analysis in Area I. Its purpose was to discover if sales can be increased by one florist without detracting from sales by competing florists, and if progressive merchandising by one florist can favorably affect sales by competing florists.

In the county seat of Area II a city sales tax was collected. From the city records, 1952 to 1959 , inclusive, indices ${ }^{14}$ were calculated for the dollar values of florists' sales volumes. ${ }^{15}$ As in Figure 1, indices also were calculated for county retail sales after floral sales had been deducted. During the last few years of the period studied, the cooperating florist (Florist B) had started a side line of garden supplies and ornamental trees and shrubs. Sales from this sicie line were deducted before calculations were made for floral products.

If data were available to record the changes in all of the variables which affect sales volumes of a given product in an area, a pattern representing the cumulative changes in these variables would coincide with a pattern representing the sales volumes of the product. Table 1 was prepared to supply data' ${ }^{16}$ (from 1952 to 1959 , inclusive) for the cumulative and simultaneous changes in purchasing power of money, in county population, in county per-capita income, and in the recurrence of death within the county. ${ }^{17}$ Figure 7 compares the resultant theoretical pattern (excluding deaths) with the parallel pattern of total, unadjusted, non-floral sales within the county. The close coincidence of the two patterns suggests that variables other than the ones included had little effect on the volume of general retail sales within Area II.

The theoretical pattern shown in Figure 8 was constructed as in Figure 7, except that one-half of the recurrence of death ${ }^{18}$ was included in the calculations. The patterns in Figure 8 , in contrast to those in Figure 7 , show wide divergencies. Something apparently exerted a strong influence on floricultural sales but not on general retail sales.

During the first four years represented in Figure 8 no correlation is suggested between sales by Florist B and sales by the other city

14 Throughout the analysis of Area 1I, all indices were expressed in percentages of the averages for the years $1953,1954,1955$.

15 These data were on the basis of the fiscal year.

16 See footnotes, Table 1.

17 See footnotes, Table 1.

18 Because recurrence of death affects only funeral sales. 
Table 1. Theoretical Changes in Dollar Volumes of Sales, 1952 to 1959, Inclusive (Based on the assumption that the only variables affecting sales were population, ${ }^{*}$ per capita income, ${ }^{* *}$ purchasing power of money ${ }^{* *}$ and in the case of floral sales, one-half the changes in recurrence of death ${ }^{* * * *}$ )

\begin{tabular}{c|c|c|c|c|c|c}
\hline Year & $\begin{array}{c}\text { Purchasing } \\
\text { Power }\end{array}$ & $\begin{array}{c}\text { Popula- } \\
\text { tion }\end{array}$ & $\begin{array}{c}\text { Per Capita } \\
\text { Income }\end{array}$ & $\begin{array}{c}\text { Cumu- } \\
\text { lative } \\
\text { Effect }\end{array}$ & $\begin{array}{c}\text { One-half } \\
\text { Recurr- } \\
\text { ence of } \\
\text { Death }\end{array}$ & $\begin{array}{c}\text { Cumu- } \\
\text { lative } \\
\text { Effect }\end{array}$ \\
\hline 1952 & 100.9 & $\begin{array}{c}\% \\
\%\end{array}$ & $\begin{array}{c}\% \\
\%\end{array}$ & $\begin{array}{c}\% \\
\%\end{array}$ & $\begin{array}{c}\% \\
99.4\end{array}$ \\
\hline 1953 & 100.1 & 101.5 & 101.7 & 100.4 & 97.9 & 101.2 \\
\hline 1954 & 99.8 & 100.0 & 97.2 & 97.0 & 100.0 & 97.0 \\
\hline 1955 & 100.0 & 98.5 & 101.1 & 99.6 & 102.1 & 101.7 \\
\hline 1956 & 98.6 & 97.1 & 112.1 & 107.8 & 107.0 & 114.8 \\
\hline 1957 & 95.3 & 95.6 & 123.0 & 113.9 & 101.3 & 115.2 \\
\hline 1958 & 92.8 & 94.2 & 126.1 & 113.1 & 100.6 & 113.7 \\
\hline 1959 & 92.0 & 92.7 & 134.0 & 118.7 & 108.9 & 127.6 \\
\hline
\end{tabular}

*United States Census of Population, General Population Characteristics, West Virginia, U. S. Department of Commerce, 1960; Table 28, pp. 50-74.

**Personal Income and Retail Sales in West Virginia, West Virginia Chamber of Commerce, April 1960, Appendix A, p. 10.

***Statistical Abstract of U. S.. U. S. Department of Commerce, 1960; Table 432, p. 331. ****Photostatic Records from $\ddot{W}$. Va. State Department of Health.

florists, ${ }^{19}$ but correlation during the last four years is indicated. ${ }^{20}$ Starting in 1955 or 1956 something caused local florists' sales to vary in unison and to diverge sharply from the theoretical pattern. Figure 8 indicates, however, that this influence acted more strongly on sales by Florist B than on his ccmpetitors' sales, but that Florist B's gains were not made at the expense of competing florists.

If the etfects of the variables included in Table 1 were removed from a series of sales volumes, the resultant pattern would indicate the presence or absence of other causal variables. As the cumulative effect of these other variables approached zero, the pattern would approach a straight line; and as their cumulative effect increased, the pattern would make a corresponding departure from a straight line.

Table 2 lists the indices used for discounting the effects of the variables listed in Table 1. The pattern constructed from Table 1 was a record of the cumulative and simultaneous annual changes of the variables themselves; but the pattern desired from Table 2 was a record of the changes not caused by these variables. Therefore the indices of change in Table 2 are the reverse of those in Table 1.

Figure 9 shows two patterns of sales derived from Table 2. Nonfloral county retail sales showed slight annual departure from a straight

19 A test for simple correlation showed an $R^{2}$ value of 0 .

20 A test for simple correlation showed an $R^{2}$ value of 78 . 
Figure 7. Actual and Theoretical Patterns of County Retail Sales Minus City Floricultural Sales (Dollar values and calcuated values from 1952 to 1959, inclusive, with the averages of 1953, 1954, and 1955 as indices Per Cent of 100 per cent)

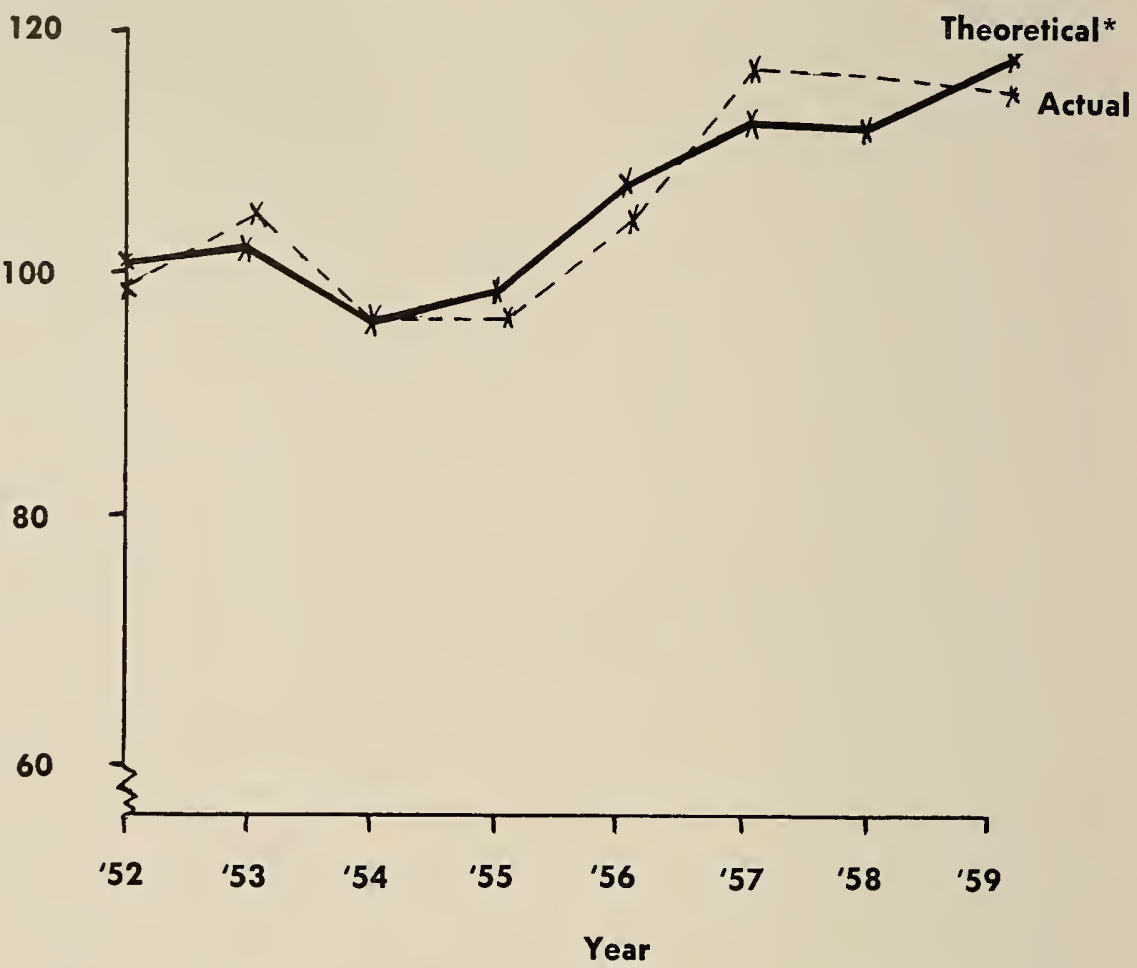

*The cumulative changes in the purchasing power of money, in population, and in per capita income, expressed as per cents of the cumulative average of 1953, 1954, and 1955. See Table 1.

Table 2. Data for Adjusting Dollar Volumes of Sales, 1952 to 1959, Inclusive (Used to discount the cumulative effect of the purchasing power of money, population, per capita income, and in the case of floral sales, of one-half the changes in recurrence of death)

\begin{tabular}{c|c|c|c|c|c|c}
\hline \hline Year & $\begin{array}{c}\text { Purchasing } \\
\text { Power }\end{array}$ & $\begin{array}{c}\text { Popula- } \\
\text { tion }\end{array}$ & $\begin{array}{c}\text { Per Capita } \\
\text { Income }\end{array}$ & $\begin{array}{c}\text { Cumu- } \\
\text { lative } \\
\text { Change }\end{array}$ & $\begin{array}{c}\text { One-half } \\
\text { Recurr- } \\
\text { ence of } \\
\text { Death }\end{array}$ & $\begin{array}{c}\text { Cumu- } \\
\text { lative } \\
\text { Change }\end{array}$ \\
\hline 1952 & $\begin{array}{c}\%^{*} \\
99.1\end{array}$ & $\begin{array}{c}\%^{*} \\
97.1\end{array}$ & $\begin{array}{c}\%^{*} \\
103.4\end{array}$ & $\begin{array}{c}\%^{*} \\
99.6\end{array}$ & $\begin{array}{c}\%^{*} \\
101.0\end{array}$ & $\begin{array}{c}\%^{*} \\
100.6\end{array}$ \\
\hline 1953 & 99.9 & 98.5 & 98.3 & 96.7 & 102.1 & 98.8 \\
\hline 1954 & 100.2 & 100.0 & 102.8 & 103.0 & 100.0 & 103.0 \\
\hline 1955 & 100.0 & 101.5 & 98.9 & 100.4 & 97.9 & 98.3 \\
\hline 1956 & 101.4 & 102.9 & 87.9 & 92.2 & 93.0 & 85.2 \\
\hline 1957 & 104.7 & 104.4 & 77.0 & 86.1 & 98.7 & 84.8 \\
\hline 1958 & 107.2 & 105.8 & 73.9 & 86.9 & 99.4 & 86.3 \\
\hline 1959 & 108.0 & 107.3 & 66.0 & 81.3 & 91.1 & 72.4 \\
\hline
\end{tabular}

- The reverse of the indices in Table 1. 
Figure 8. The Theoretical Pattern of Local Floricultural Sales and the Actual Patterns of Sales by Florist B and by the Other City Florists (Dollar values of actual sales and the calculated values, 1952 to 1959, inclusive, with the averages of 1953, 1954, and 1955 as indices of 100 per cent) Per Cent

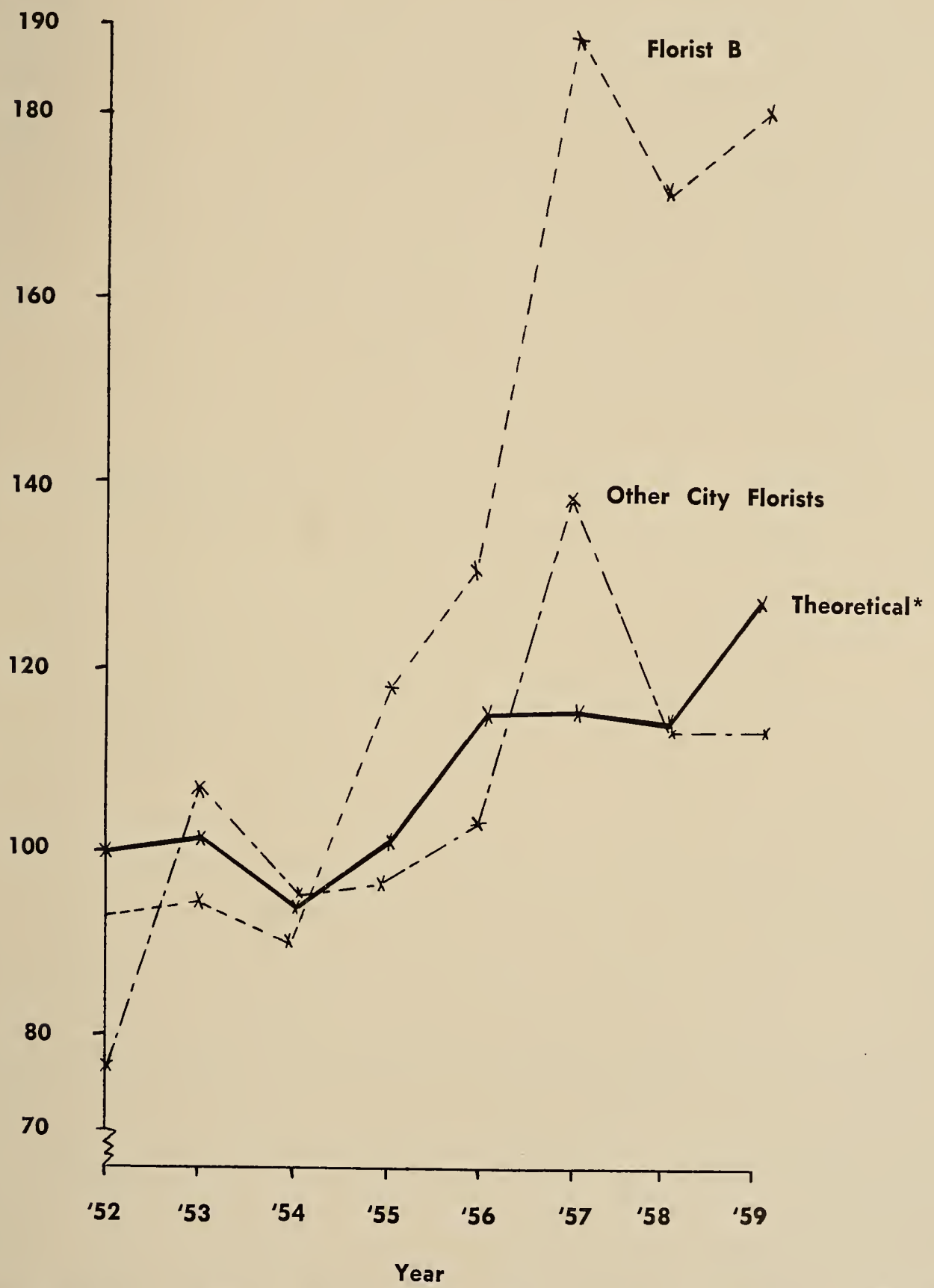

*The cumulative changes in the purchasing power of money, in population, in per capita income, and in one-half of the recurrence of death in the county. See Table 1. 
Figure 9. Floral Sales of Florist B and County Retail Sales Minus City Floral Sales (Adjusted* values for 1952 to 1959, inclusive, with the averages of 1953,1954 , and 1955 as indices of 100 per cent)

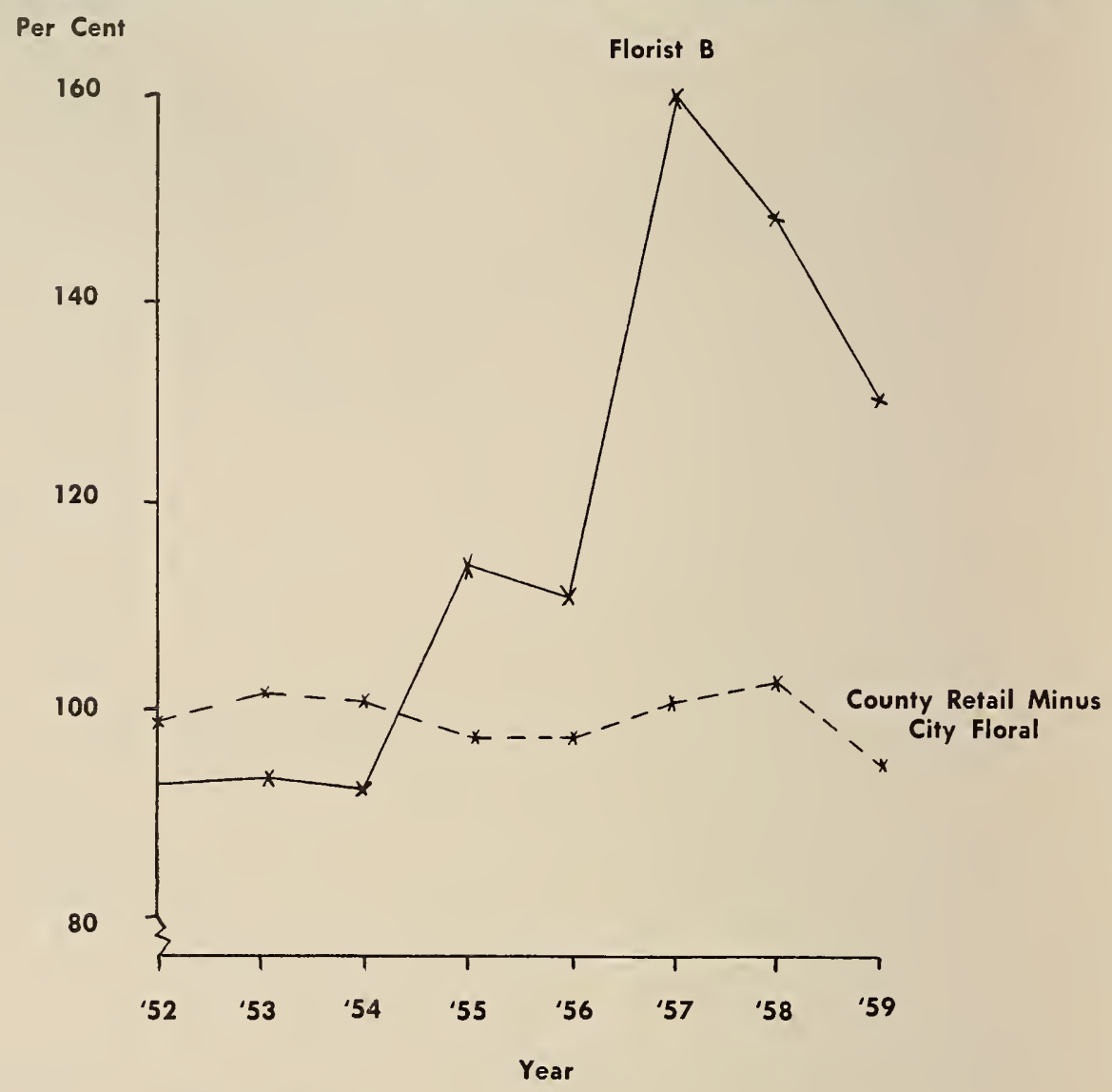

*See Table 2.

line, but starting in 1954, the pattern of floricultural sales by Florist B diverged greatly from a straight line. In the case of general retail sales the difference was comparatively slight between the average sales volumes of the first and of the last four years; but these differences in the case of Florist B were relatively large. A similar discrepancy would have happened by chance less often than once in one hundred times. ${ }^{21}$

Figure 10, also prepared from Table 2, shows that after 1954 the patterns for floral sales by Florist $B$ and by other city florists were quite similar. However, the sales by Florist B departed farther from a straight line than sales by the other florists. The difference between the averages of the first and last four years was much greater for sales by Florist $\mathrm{B}$ than for sales by the other florists. This discrepancy also

21 A Chi Square value of 6.63 was needed for the 1 per cent level; 738.98 was obtained. 
Figure 10. Floral Sales of Florist B and of the Other City Florists (Adjusted* values for 1952 to 1959, inclusive, with the averages of 1953, 1954 and 1955 as indices of 100 per cent)

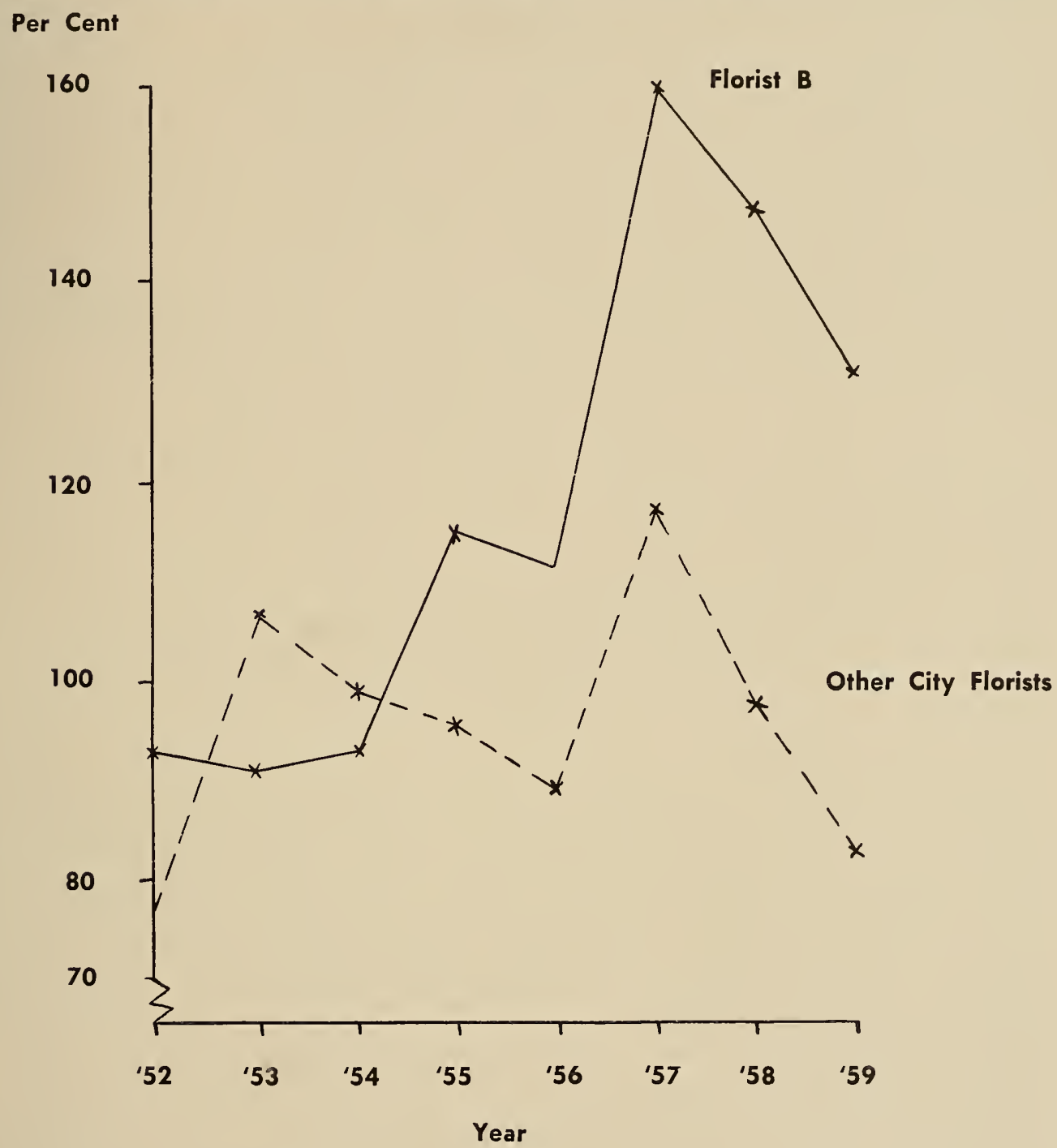

-See Table 2 .

would have happened by chance less often than once in one hundred times. $^{22}$

Figure 11 shows the patterns of adjusted county non-florist sales and adjusted sales by city florists other than Florist B. During six of the eight years studied, sales by florists and by non-florists were less than the base average $(1953,1954,1955)$. However, the pattern of florists'

22 A Chi Square value of 6.63 was needed for the 1 per cent level; 916.85 was obtained. 
Figure 11. Floral Sales by City Florists Other Than Florist B and County Retail Sales Minus City Floral Sales (Adjusted* values for 1952 to 1959, inclusive, with the averages of 1953, 1954, and 1955 as indices of Per Cent

100 per cent)

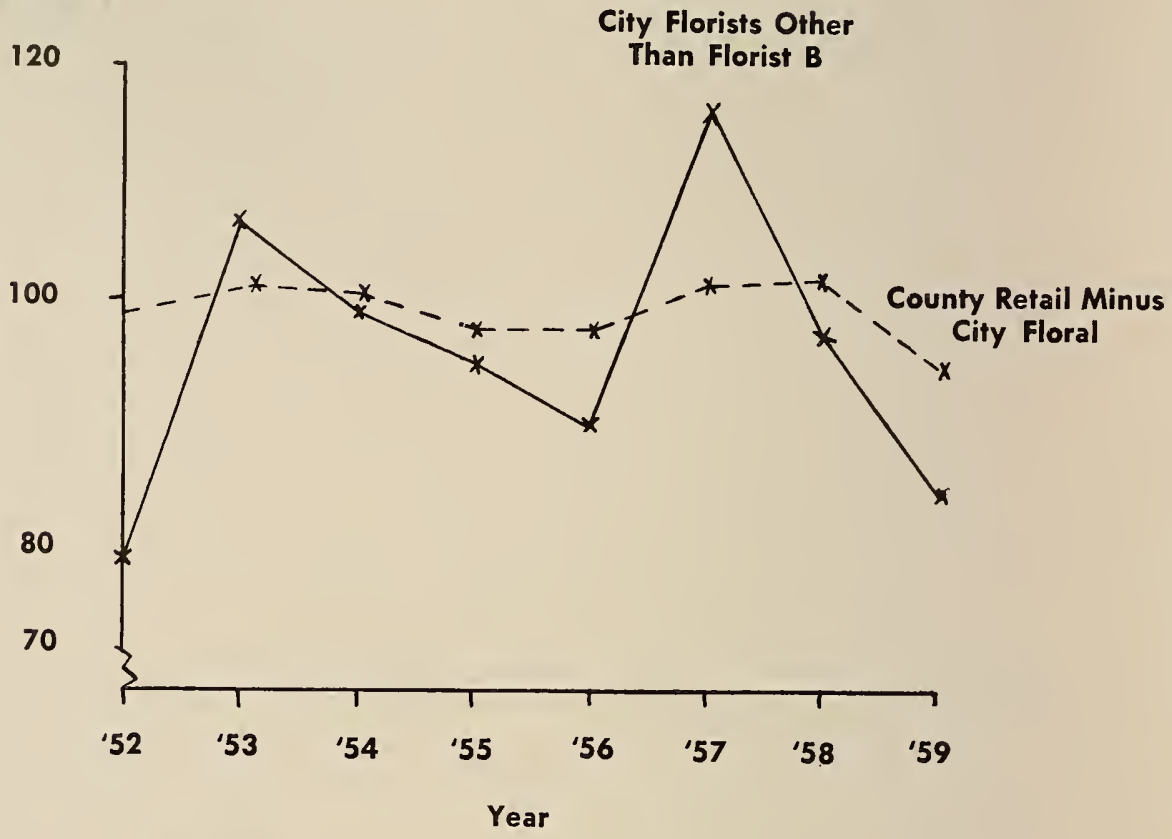

*See Table 2 .

sales varied from a straight line more than the pattern of non-florist sales. The last four-year average of florists' sales was larger than the first four-year average, but the last four-year average of non-florists sales was the smaller. Although this difference between florist and non-florist sales patterns was statistically significant, ${ }^{23}$ it was considerably smaller than the difference between the sales patterns for .Florist $B$ and for non-florists. ${ }^{24}$

The analysis has indicated that some influence other than the ones included in Table 1 (and Table 2) affected sales both by Florist B and by the other local florists (Figure 9); that this influence affected Florist B's sales more than his competitors' (Figure 9); that it made little or no impression upon non-florist sales (Figure 8); and that gains by Florist $\mathrm{B}$ were not made at the expense of his competitors, but that the factors which expanded Florist B's sales also expanded sales by his competitors (Figures 9 and 10).

23 A Chi Square value of 3.84 was needed for the 5 per cent level; 5.52 was obtained.

24 Significant at the 1 per cent level. See footnote 21. 
If prices for floral products within the area had been manipulated while demand remained constant, numerical volumes of sales would have been affected, but dollar volumes would have tended to remain constant. However, all of the sales volumes reported were in terms of dollar volume. A series of sharp changes in the prices of goods which compete with floral products might have caused the variations among florists' sales. The No flowers, please moviment made no noticeable changes during the period; candy and condiments are only partial substitutes for floral products, since funerals, marriages, church events, and Memoral Day, are not occasions especially associated with candy. Competition among chain stores, independent grocery stores, drug stores, and gift and novelty shops would have prevented unusual price fluctuations in the local candy and condiment market.

Close association is not necessarily proof of a cause and effect relationship; but close association between specific efforts to broaden the market and adjusted dollar volumes of sale is strongly indicative of cause and effect. Various efforts to broaden the market for floral products were made by Florist B. He believed that florist shops often make visitors feel unwelcome, and therefore he decided to inaugurate a program to encourage visitors and to minimize the shop's atmosphere of formality. Starting during the Christmas season of 1956, he featured one open house each year. Radio and newspapers were used to publicize the events. Post cards were sent to a selected list of patrons. No selling was done during the 1956 event, but a register was kept of guests in attendance, and souvenirs and door prizes were given. Special care was taken in arranging Christmas displays, and cake and coffee were served to the guests. A conscious effort was made toward a social rather than toward a commercial atmosphere. The register indicated 450 guests in 1956, 600 in 1957, and 750 in 1958. Attendance in 1958 was about 10 per cent of the city's population. The shop was so crowded in 1958 that in 1959 the open house was held for three consecutive days. Each visitor was taken on a tour of the shop. During the 1959 event the guests were allowed to place orders and to make purchases. About 80 per cent of the 400 registered guests took advantage of the opportunity. However, many visitors did not register in 1959.

The management prepared the following report about other special events:

Other Special Events were the Greenhouse Plant Sales in late May and early June of both 1958 and 1959. It is argued that selling 'left over' flower and garden transplants, etc., at reduced rates, is a poor business practice, but we do not reduce our prices until we reach the point where it becomes an expense in care or space for us to continue to carry them. We feel we don't lose any 'peak of season' sales. In many cases our own regular customers return to buy a few 'extras' and often see garden supplies or other items and make a good purchase. We run these sales from three to six days and make enough to pay for advertising and selling, etc. 
A small garden supply center was started in 1956. It was established more to encourage visitors than to become an important part of the business. During the next year ornamental trees and shrubs were marketed from a conspicuous display area. Landscape work was done on a limited basis. The management believed that the garden center did not pay its way, but that it may have encouraged visitors.

The greenhouse was maintained in a manner to encourage visitors to "browse." Beds were seldom empty, trash was kept to a minimum, and aisles were dry and clear.

The expansion of the area's total florist sales and Florist B's drive to encourage visitors were closely associated. During the period between the first and second open houses, the dollar volumes of sales by Florist $\mathrm{B}$ rose almost 50 per cent (Figure 10), and his competitors' sales rose about 30 per cent. During this same period special greenhouse sales were inaugurated and the garden center was opened. In the absence of conflicting, specific evidence it might logically be concluded that this broadening of adjusted, local flower sales indicates that such sales are responsive to progressive merchandising techniques, and that a local demand for floral products can be increased, at least temporarily. During 1958 and 1959, Florist B's adjusted sales dropped proportionately more than adjusted county non-floral sales. This disproportionate drop may indicate that innovations must be devised progressively to maintain a demand which recently has been increased by affecting consumer tastes and preferences. 


